\title{
Impact of herding behavior and overconfidence bias on investors' decision-making in Pakistan
}

\author{
Muhammad Qasim, Rana Yassir Hussain*, Intkhab Mehboob and Muhammad Arshad
}

University of Education, Lahore (Jauharabad Campus), Pakistan

\begin{tabular}{l}
\hline C H R O N I C L E \\
\hline Article history: \\
Received March 3, 2018 \\
Received in revised format June \\
112018 \\
Accepted July 32018 \\
Available online \\
July 4 2018 \\
\hline Keywords: \\
Herding Behavior \\
Overconfidence Bias \\
Decision making \\
OLS \\
\hline
\end{tabular}
A B S T R A C T

\begin{abstract}
Investors' decision-making are influenced by certain biases as reported in literature. Fundamental analysis is based on the assumption that investors think rationally, but in practice, things may be different. This study captures the impact of herding behavior and overconfidence biases on the investors' decision-making in Pakistan. The proposed study collects the necessary data through questionnaires distributed among 150 respondents who were active in stock market and manage to process 100 completed ones. The relationships between investors' decision-making and herding behavior as well as overconfidence biases were empirically tested using Ordinary Least Square (OLS) method. The results show that Pakistani investors' decisions were significantly influenced by both herding behavior and overconfidence biases.
\end{abstract}

\section{Introduction}

Recently, different modes of investment have become popular and investors make a decision about the selection of investment differently. The earliest theories of economics show that the individual is rational and make decisions by evaluating all information, which is available. As time passes, it becomes difficult for the investors to make their investment decision because they have to consider various factors before making decision. In the past, the investors had limited information to make a decision and make a decision on some information, which were easily available, but with advancements in technology, investors have to face large information heaps to make a decision.

The investors anchor themselves with some information and make decisions based on that one. The anchoring is more common in women than men (Matsumoto et al., 2013). Another important factor is personality and other circumstances, which influence on investor's decision (Kahneman \& Tversky, 1972). The investor's decision is also affected by different psychological biases (Hirshleifer, 2001). Investor's mood affect their investment decision, if the mood is good, then investors take more risk and vice versa (Grable \& Roszkowski, 2008). Ngoc (2013) studied the effects of behavioral bias on investors' decision at the Securities Companies in Ho Chi Minh City, Vietnam. The findings indicate that the biases affected investors' decision, significantly. Lewellen (2006) estimated volatility, cost of debt and study their impacts on financial decision in some US firms. The findings indicate that volatility and cost influenced on the financial decision.

* Corresponding author

E-mail address: yhussain0004@yahoo.com (R. Y. Hussain) 
It is not possible for the investors to properly evaluate the whole information and make investment decisions well. The financial prices reflect the whole information, which is available in the market, and prices are the best source to make a decision (Shiller 2003). There are also different factors that affect the investment decision like rumors, availability of information related risk and return, individual background, behavioral biases, etc. The behavior biases affect the prices, the prices set by risk averse and risk seeker will be different (Coval \& Shumway, 2005). Aspara and Tikkanen (2011) studied whether company motivate investors to invest on stocks beyond their risk and return. They used a survey method and collected the necessary data from four hundred individuals. The findings indicate that the investor had extra motivation to invest in stock beyond the risk and returns of the stock.

There are two types of investors, according to gender, male and female. The preferences of both male and female investors are different. The first group is more risk taker than the second one (Croson \& Gneezy, 2009). The confidence level of both types of genders are also different (Bengtsson et al., 2005). The self-attribution bias makes investors overconfident (Hoffman \& Post, 2014). Those investors are confident who are well educated. If an investor is confident, his/her trading frequency will increase too (Graham et al., 2009). A person becomes overconfident through his/her success (Gervais et al., 2002). The time duration of investments, also affect the investment decision. The trait of short-term investor is different from the long-term investor (Lakshmi et al., 2013). The investors judge the worth of securities on the basis of an image of security. Any investor to evaluate securities uses the imagery but performance will not be judged on these factors (Macgregor et al., 2000).

The investor does not make investment in only one country instead of making investment in different countries. The investor makes investment decision in different timeframe and reduces the impact of biases (Keysar et al., 2012). These are different biases that affect the investment decision. If the investor understands all biases, then it is helpful for investors to make better financial decisions (Suresh, 2013). In our study, we focus on two biases; namely overconfident and herding behavior. The impact of these biases on the decision making of Pakistani investors is studied in this research. There is a lot of works performed in this field throughout the world. However, in Pakistan, there are limited studies in this context and it is also important because the behavior and personality of each person are different. In this research, we study how these biases affect the decision of Pakistani investors.

The study outcomes are very useful for financial advisor, financial institutions and for the investors. These are helpful to understand how the investor deviates from their rational decisions. These could not include all types of bias, but it is helpful to understand the investor's decision-making behavior. It will be helpful for the financial institutions to understand the behavior and psychology of investor and help them guide the clients in the future direction of the investment. The financial institutions also used to guide their clients from losing their investment. This study also contributes in existing literature by exploring the impact of biases on investment decision. That study is also helpful to the students and other academic purposes.

\section{Literature review}

Different economic theories say that the investors are rational, means they process full information before making a decision. It proved wrong through Kahneman and Tversky (1972) two-factor theory. He said the personality and situation affect the decision of the investor. In daily life, a person makes different types of important and unimportant decisions. When an investor makes the important decision then he/she gets information from different sources and then evaluates that information to make a decision. That is not possible in all conditions to evaluate the whole information then he/she adopts shortcuts to make a decision.

\subsection{Herding behavior and decision making}

Herding behavior means following the other investors action with no due diligence. In herding behavior the investor imitates the work of other, which means if one investor chooses security " $A$ ", others also 
invest in security without making their own strategies. Decision, is the selection of one alternative from the all-available choices. When we see it in investment contest, it means selecting the best alternative or the investments, which give maximum benefit. The economic theories say that the investors are rational and they evaluate the whole information before making a decision, but it is not possible in the real life because there should be a large amount of information and it is not possible for the investor to evaluate the whole information. Therefore, investors choose a short cut to make a decision. When investors make decisions, they require a large amount of information and proper information. If information is not accurate or not on the right side, then investor could evaluate it and face a loss of investment. Individual investors do not normally receive the information because they do not have the access to enough resources. On the other side, the institutional investors get that information because they have large resources so in order to get the advantage of this information the individual investor follows the institutional investor to make a rational decision.

Lakshman et al. (2013) studied market wide herding in Indian capital market and found the impact of volatility and return on herding behavior of institutional investors. The results indicate that the herding behavior exists in the market. Chen and Pelger (2013) identified the impact of compensation on the herding behavior through Black-Scholes model. The results showed that herding driven by manger risk aversion and the relative compensation. Chiang et al. (2013) examined the investor herding behavior in pacific- Basin equity market. The result indicated that the herding behavior is varied in both bearish and bullish market. It also indicated that herding was positively related to market performance and negatively related to the market volatility.

Cipriani and Guarino (2012) studied the importance of herding behavior in the financial markets by taking data on Ashland Company listed on the New York stock exchange. The result showed that it affects buy, sell of traders, and affect prices of assets. Demirer and Kutan (2006) studied the impact of herding information in Chinese market by using individual and sector level data. They also found the return dispersion during period of upward and downward change in the market index. The result showed that the herding behavior does not exist in the Chinese market and equity return dispersion was significantly higher at period of large change in aggregate index. The findings also support the market efficiency and asset-pricing model. Drehmann et al. (2004) studied the impact of herding and contrarian behavior in financial market using internet experiment design. In this experiment 264 consultants of international firms, participated. They reported that flexible market prices prevent the herding behavior and contrarian behavior rationalize by error model and distort prices. Hsieh et al. (2008) studied the impact of herding behavior and positive feedback on the capital inflow by taking EPRF data of Latin America and Asia. The result showed that capital and positive feed information exist in emerging markets so the herding effect exists. Kallinterakis and Kratunova (2007) studied the impact of thin trading on the herding behavior in Bulgarian market by using Hwang and salmon (2004) measure. The result showed that the thin trading reduces the herding behavior.

Oehler and Wendt (2009) found the herding behavior of mutual fund in Germany by taking data of manager buying and selling over the period 2000-2005. The result showed that they invest 70 percent in the equity market, which clearly showed that there is a significant herding behavior in the equity market. Ornelas and Alemanni (2008) analyzed herding behavior in emerging markets by taking data of nine emerging markets from 2000 to 2005. The investigation show that the herding exists in emerging markets. It also showed that the herding had no impact on volatility. Oehler and Chao (2000) studied the institutional herding in the bond market by taking data from 57 German mutual fund companies, which invest mainly in DM-dominated bond and it is 71 percent of the market volume. Their results showed that there was a strong herding behavior in the bond market. Puckett and Yan (2008) studied the impact of short-term institutional herding on the stock prices by taking trade of 776 institutional investors from 1999 to 2004 . They reported that the short-term sells motivated by behavior and the prices are deviated significantly from fundamental value. Redding (1996) studied the noise trader and herding behavior. The results showed that the prices significantly were deviated from their fundamental value. Raddatz and Schmukler (2011) analyzed the herding behavior of pension fund 
managers by analyzing unique, monthly asset-level data from the pioneer case of Chile. The result showed that the fund manager follows the strategies of each other in order to maximize profit and reduce the risk. Arouri et al. (2010) analyzed the herding behavior of institutional investor in the French equity market by taking data from 2000 to 2005 . The results showed that herding is more common in small firm as compared to large and medium size firms. Venezia et al. (2009) investigated the herding behavior of amateur and professional investors using a unique data of daily translation and of four years. The result showed that the herding is greater among armature investors compared with professionals. Wang (2008) studied the herd behavior of market index by using state space models. They studied the herding measure around the sudden event like financial crisis 1997-1998. The result analyzed that herding was greater in emerging markets than the developed market. Yao (2010) studied the herding behavior through the trade volume by using Hwang and Salmon (2004) measure on the Toronto Stock Exchange. The results revealed that herding consists of three components. First is the signal about market condition. Second is the intentional herding relative to the anticipations of the investors and third current herding depends upon the previous herding.

Hypothesis 1: The herding behavior has significant and positive effects on the investment decision.

\subsection{Decision-making and overconfidence}

Overconfidence overestimates the actual performance of the securities. The economic theories say that the investors are rational and they evaluate the whole information before making a decision, but it is not possible in the real life because there should be a large amount of information and it is not possible for the investors to evaluate the whole information.

Therefore, investors choose a short cut to make a decision. When the investor is over confident then he/she takes a more risk and if he/she is overconfident, then his/her decision is not rational. When an investor makes investment then he/she evaluates the information and makes decisions based on that information. When he/she is overconfidence then he makes investment decision based on their beliefs, not by evaluating whole information as a result the decision are not rational. Aspara and Tikkanen (2011) studied whether company motivate investors to invest in stock beyond its risk and return. They used a survey method and collect data from four hundred individual. The findings indicate that the investor has extra motivation to invest in stock beyond the risk and returns of the stock.

Parrino et al. (2002) studied the investment distortions when risk-averse managers decide whether to undertake risky projects, by getting data from the public companies. They studied the magnitude of distortion level in the investment decision. The results indicate that when the investors are risk averse, then they distort their investment and get money from the equity holder instead of the debt opportunity. Shaw (1996) studied the empirical analysis of the risk aversion and income growth by using data of finance survey. The results indicate that the wages were positively related to risk taking and risk taking attitude depended on the knowledge of the investor it also affect the return.

Baber and Odean (2001) studied the overconfidence in the gender and its impact on the trading activities by taking data 35000 household data from 1991 to 1996. The result indicates men are more confident than women are so their trading is greater, it also showed that their returns will decrease to 2.45 percent in men and 1.75 percent for women. Biais et al. (2005) studied the impact of judgmental overconfidence and self-mongering bias in the investment decision by observing the behavior of 215 participants. The results showed that under calibration reduces and self-monitoring enhances trading performance. Bailey et al. (2011) studied the impact of behavior biases on the mutual fund investments. The results showed that the mutual fund investors make a poor decision and they could not make a rational decision. Chen et al. (2007) studied the impact of disposition effect, representative bias, experience and overconfidence bias on decision making of emerging market investor by collecting brokerage data of china. The result showed that the investors make a poor decision and biases had a significant effect on investor decision. Deshmukh et al. (2009) studied the impact of the managerial 
confidence in the dividend policy. The results indicate that dividend policy had a significant effect on the dividend policy. Deaves et al. (2008) studied the overconfidence and gender on the trading activity. The result showed that the overconfidence affects the trading activities and gender impact the trading activities. Dittrich et al. (2005) investigated the impact of overconfidence and risk aversion on the investment decision. The results showed that the deviation from the optimal choices increase as the investor become overconfident. In addition, it decreases when the investor is risk averse. Fairchild (2005) studied the effect of overconfidence and asymmetric information on the financial choice of investor. The results indicate that the overconfidence increases, the manager to get more debt. The overconfident for loan is beneficial for the shareholder because it increases the equity of the shareholders.

Gervais and Goldstein (2003) studied the impact of the overconfidence on the team performance. The result showed that the overconfidence increases the performance of the team. Glaser and Weber (2007) studied the impact of overconfidence on the trading volume by using questionnaire technique. The result showed that the overconfidence increases the trading volume of individual investors.

Ngoc (2013) studied the behavioral bias impact on investor decision at the Securities Companies in Ho Chi Minh City, Vietnam. The findings indicate that these biases affect investor decision. Lewellen (2006) estimated volatility, cost of debt and their impacts on financial decision. The findings indicate that the volatility affects the financial decision.

Hirshleifer and Luo (2001) studied the survival of overconfident trader in competitive equity markets and the overconfident performed better than rational investors did. Jhandir and Elahi (2014) found the impact of three biases on the investment decision by taking the investor type as moderator variable using regression and two least square methodologies. The results showed that the overconfidence, disposition and herding behavior had a positive and significant impact on investment decision. Libby and Rennekamp (2012) investigated the impact of overconfidence and self-attribution bias in the management forecasts using the survey method.

Malmendier and Tate (2005) studied that either the overconfidence could affect the decision of the corporate investment. Oliver (2005) studied the impact of the confidence on the capital structure by getting the data of those companies of US, which exist for the 25 year. The confidence of the manger increases the debt level. The result indicates that the management confidence increases the debt level in the capital structure. Park et al. (2010) investigated the impact of overconfidence bias and confirmation bias on the investment performance by getting data from 502 investors in the South Korea. The results showed that the confirmation makes the investor overconfident and it adversely affects the performance of the investor trading. Skała (2008) studied the overconfidence in psychology and the financial structure of the corporation. The results indicate that the overconfidence had a significant effect on the financial structure of the company and it helpful in merger and acquisition.

Hypothesis 2: The overconfidence bias has a significant positive effect on investor decision making.

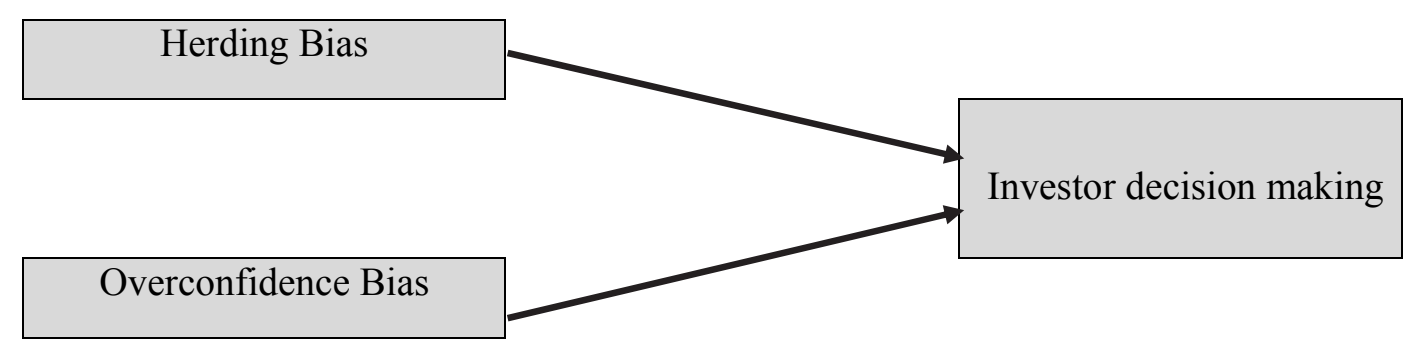

Fig. 1. The structure of the proposed method 


\section{The proposed study}

\subsection{Sample and procedure}

The population for this research includes all investors in Pakistan, who make investment in the different securities. The sample is selected by using the convenience sampling method. We use this method because of its benefit to easily access the respondent.

The sample consists of all types of investors who invest in different securities like investment in money market instrument, capital market and in other financial institutions. The survey is distributed in different banks and individual investors. The overall 150 questionnaire are distributed from which 120 are collected back and only 100 questionnaires are properly filled. This indicates that the respondent responses are the $67 \%$. Out of the hundred respondents, 59 are male and 41 are female which indicate the percentage of $59 \%$ and $41 \%$. Out of 100 respondents the $28 \%$ is under twenty and $62 \%$ are between 20-30, it indicates that many of the investors are youngster, $8 \%$ are of middle age between $30-40$. The out of hundred $54 \%$ are graduates, $20 \%$ are intermediate, $12 \%$ are masters, $8 \%$ are M-Phil and $5 \%$ are $\mathrm{PhD}$. In rupees the $29 \%$ respondents had income ranging $(21,000$ to 40,000$), 26 \%$ had income between (41,000 to 60,000$), 25 \%$ had below $20000,15 \%$ had income between $(61,000$ to 80,000$)$ and only $5 \%$ had income more than 100,000 .

\subsection{Measures}

The primary data are collected by using the questionnaire of 21 items. The Likert scale questionnaire has been used for collecting the data from respondents. It is five point Likert scale from 1-5. One= strongly disagree, $t w o=$ disagree, three $=$ neutral, four $=$ agree and five $=$ strongly agree. The herding bias is measured by adopting four-item questionnaire of Nagoc (2013). The reliability value for this variable is 0.61 . Over-confidence bias is measured by adopting questionnaire designed by Nada and Moa'mer (2013). The reliability of the overconfidence bias questionnaire is 0.66 .

This tells the behavior of investor on whether or not they learn from mistakes. The individual investment decisions are determined by using the five-item questionnaire by Aspra and Tikkanen (2011). The reliability value of that factor is the 0.65 . It helps us determine the effect of individual on their investment decision.

\section{Table1}

Means,Standard deviations and Correlation

\begin{tabular}{lllcccc}
\hline & & Mean & SD & $\mathbf{1}$ & $\mathbf{2}$ & $\mathbf{3}$ \\
\hline 1 & DM & 3.4600 & 0.62628 & 1 & & \\
2 & HB & 3.4600 & 0.72624 & $0.250^{*}$ & 1 & 1 \\
3 & OCB & 3.5100 & 0.56696 & $0.232^{* *}$ & $0.331^{* *}$ & 1 \\
\hline
\end{tabular}

Table 1 represents the descriptive statics and the correlation between the dependent and independent variables. The mean for herding bias is 3.4600 and standard deviation is 0.72624 . The means of overconfidence bias in 3.5100 and standard deviation is 0.56696 . The mean and standard deviation of risk aversion bias are 3.4600 and 0.64937 , respectively. The means for investment decision making is the 3.4600 and standard deviation is 0.62628 . The correlation matrix indicates the relationship between the investment decision and HB is 0.250 , which shows that the relationship is positive. The correlation between the investment decision making and over confidence bias is positive and it is 0.232 . The relationship between the investment decision making and risk aversion bias is positive and its value is 0.249. Linear regression is used to test the hypothesis. The hypothesis predicts that the biases are positively affecting the investment decision. Regression is run by controlling the demographics variable. Regression analysis showed that the $p$-value for overconfidence bias is 0.00456 at $p<0.05$ which indicates that the relationship is positive and significant. The p-value for the Herding bias is 0.0037 at $p<0.05$, which indicates that the Herding bias has strong impact on the investment decision. 
The results support the all hypothesis. Hypotheses are supported by the results. The value of R square change is 4 which indicate that which have an overall significant impact on the impact decision.

Table 2

Regression analysis outcomes

\begin{tabular}{llll}
\hline Predictors & Intercept & p-value & R-square \\
\hline HB & 0.265 & 0.00375 & 0.346 \\
OCB & 0.270 & 0.00456 & \\
\hline
\end{tabular}

\section{Discussion and conclusion}

As time passes the investors' behaviors in financial investment have become important and large number of studies have been performed in that field. Many researchers attracted to that one because it is an emerging field and now the risk aversion becomes popular throughout the world. This study focused on the impact of two biases in the investment decision; namely herding bias and overconfidence bias. The previous studies also indicate that it had significant impact on the investment decision. This study also focused on identifying the impact of these biases on the investment decision of the Pakistani investor.

The results of this study also support our hypothesis, the impact of biases on the investment decision. The herding bias has positive impact the investment decision. The overconfidence bias has a positive and significant impact on the investment decision.

The results also indicate that the herding bias has strong impact on the investment decision. The Pakistani markets are not well developed and efficient, so information is not equally available to everyone. So in order to protect from the loss the small investors imitate the strategies of the big financial institutions. The investors are affected by herding bias because of two reasons, first to protect themselves from the loss and the second to reward with a maximum profit (Raddatz \& Schmukler, 2011).

Herding behavior of the investor also depends on the market performance if the market performance is better than the herding (Chiang et al., 2013). The results are supported by Malmendier and Tate (2005) and Jhandir and Elahi (2014)

The results of the study have indicated that the over-confidence bias had significant and positive impact on the investment decision making. Any individual may become overconfident when his/her education and experience will increase. The previous studies have indicated that males are more confident than female and their impact on decision is significant (Baber \& Odean, 2001). When an individual is overconfident than his decision is not well and appropriate. In other words individual make a poor decision (Chen et al., 2007).

\section{Acknowledgement}

The authors would like to thank the anonymous referees for constructive comments on earlier version of this paper.

\section{References}

Arouri, M. E. H., Bellando, R., Ringuedé, S., \& Vaubourg, A. G. (2010). Herding by institutional investors: empirical evidence from French mutual funds.

Aspara, J., \& Tikkanen, H. (2011). Individuals' affect-based motivations to invest in stocks: Beyond expected financial returns and risks. Journal of Behavioral Finance, 12(2), 78-89.

Barber, B. M., \& Odean, T. (2001). Boys will be boys: Gender, overconfidence, and common stock investment. The Quarterly Journal of Economics, 116(1), 261-292. 
Bailey, W., Kumar, A., \& Ng, D. (2011). Behavioral biases of mutual fund investors. Journal of Financial Economics, 102(1), 1-27.

Biais, B., Hilton, D., Mazurier, K., \&Pouget, S. (2005). Judgemental overconfidence, self-monitoring, and trading performance in an experimental financial market. The Review of economic studies, 72(2), 287-312.

Bengtsson, C., Persson, M., \& Willenhag, P. (2005). Gender and overconfidence. Economics letters, 86(2), 199-203.

Chen, G. M., Kim, K., Nofsinger, J. R., \&Rui, O. M. (2007). Trading performance, disposition effect, overconfidence, representativeness bias, and experience of emerging market investors. Disposition Effect, Overconfidence, Representativeness Bias, and Experience of Emerging Market Investors (January 2007).

Chen, A., \&Pelger, M. (2013). How Relative Compensation can lead to Herding Behavior.

Chiang, T. C., Li, J., Tan, L., \&Nelling, E. (2013). Dynamic herding behavior in Pacific-Basin markets: Evidence and implications. Forthcoming in Multinational Finance Journal.

Cipriani, M., \&Guarino, A. (2012). Estimating a structural model of herd behavior in financial markets. FRB of New York Staff Report, (561).

Coval, J. D., \& Shumway, T. (2005). Do behavioral biases affect prices?. The Journal of Finance, 60(1), 1-34.

Croson, R., \& Gneezy, U. (2009). Gender differences in preferences. Journal of Economic literature, 47(2), 448-74.

Demirer, R., \&Kutan, A. M. (2006). Does herding behavior exist in Chinese stock markets?. Journal of international Financial markets, institutions and money, 16(2), 123-142.

Deaves, R., Lüders, E., \& Luo, G. Y. (2008). An experimental test of the impact of overconfidence and gender on trading activity. Review of finance, $\mathrm{rfn} 023$.

Deshmukh, S., Goel, A. M., \& Howe, K. M. (2009). CEO overconfidence and dividend policy (No. 2009-06). Working Paper, Federal Reserve Bank of Chicago.

Dittrich, D. A., Güth, W., \&Maciejovsky, B. (2005). Overconfidence in investment decisions: An experimental approach. The European Journal of Finance, 11(6), 471-491

Drehmann, M., Oechssler, J., \&Roider, A. (2004). Herding and contrarian behavior in financial markets-an internet experiment. Available at SSRN 650462.

Fairchild, R. J. (2005). The effect of Managerial Overconfidence, asymmetric information, and moral hazard on capital structure decisions. Available at SSRN 711845.

Grable, J. E., \& Roszkowski, M. J. (2008). The influence of mood on the willingness to take financial risks. Journal of Risk Research, 11(7), 905-923.

Gervais, S., \& Goldstein, I. (2003). Overconfidence and team coordination.Available at SSRN 470787.

Gervais, S., Heaton, J. B., \& Odean, T. (2002). The positive role of overconfidence and optimism in investment policy. RODNEY L WHITE CENTER FOR FINANCIAL RESEARCH-WORKING PAPERS-

Glaser, M., \& Weber, M. (2007). Overconfidence and trading volume. The Geneva Risk and Insurance Review, 32(1), 1-36.

Graham, J. R., Harvey, C. R., \& Huang, H. (2009). Investor competence, trading frequency, and home bias. Management Science, 55(7), 1094-1106.

Hirshleifer, D. (2001). Investor psychology and asset pricing. The Journal of Finance, 56(4), 15331597.

Hirshleifer, D., \& Luo, G. Y. (2001). On the survival of overconfident traders in a competitive securities market. Journal of Financial Markets, 4(1), 73-84.

Hoffmann, A. O., \& Post, T. (2014). Self-attribution bias in consumer financial decision-making: How investment returns affect individuals' belief in skill. Journal of Behavioral and Experimental Economics, 52, 23-28. 
Hsieh, S., Tai, Y. Y., \& Vu, T. B. (2008). Do herding behavior and positive feedback effects influence capital inflows? Evidence from Asia and Latin America. The International Journal of Business and Finance Research, 2(2), 19-34.

Hwang, S., \& Salmon, M. (2004). Market stress and herding. Journal of Empirical Finance, 11(4), 585-616.

Jhandir, S. U., \& Elahi, M. A. (2014, May). Behavioral Biases in Investment Decision Making and Moderating Role of Investor's Type. In SZABIST's 20th National Research Conference, 10th May.

Kallinterakis, V., \&Kratunova, T. (2007). Does thin trading impact upon the measurement of herding? Evidence from Bulgaria. Evidence from Bulgaria.

Kahneman, D., \& Tversky, A. (1972). Subjective probability: A judgment of representativeness. Cognitive Psychology, 3(3), 430-454.

Keysar, B., Hayakawa, S. L., \& An, S. G. (2012). The foreign-language effect: Thinking in a foreign tongue reduces decision biases. Psychological science, 23(6), 661-668.

Lakshman, M. V., Basu, S., \& Vaidyanathan, R. (2013). Market-wide herding and the impact of institutional investors in the Indian capital market. Journal of Emerging Market Finance, 12(2), 197-237.

Lakshmi, P., Visalakshmi, S., Thamaraiselvan, N., \& Senthilarasu, B. (2013). Assessing the Linkage of Behavioural Traits and Investment Decisions using SEM Approach. International Journal of Economics \& Management, 7(2).

Lakonishok, J., Shleifer, A., \& Vishny, R. W. (1992). The impact of institutional trading on stock prices. Journal of financial economics, 32(1), 23-43.

Lewellen, K. (2006). Financing decisions when managers are risk averse.Journal of Financial Economics, 82(3), 551-589.

Libby, R., \& Rennekamp, K. (2012). Self-Serving Attribution Bias, Overconfidence, and the Issuance of Management Forecasts. Journal of Accounting Research, 50(1), 197-231.

MacGregor, D. G., Slovic, P., Dreman, D., \& Berry, M. (2000). Imagery, affect, and financial judgment. The Journal of Psychology and Financial Markets, 1(2), 104-110.

Malmendier, U., \& Tate, G. A. (2005). Does overconfidence affect corporate investment? CEO overconfidence measures revisited. European Financial Management, 11(5), 649-659.

Matsumoto, A., Fernandes, J., Ferreira, I., \& Chagas, P. (2013). Behavioral Finance: A Study of Affect Heuristic and Anchoring in Decision Making of Individual Investors.

Ngoc, L. T. B. (2013). Behavior pattern of individual investors in stock market. International Journal of Business and Management, 9(1), 1.

Nada, S. M. A., \&Moa'mer, F. A. (2013). Deanery Of Higher Studies Faculty Of Commerce Dep. Of Business Administration

Oehler, A., \& Chao, G. G. C. (2000). Institutional herding in bond markets.Bamberg University Dept. of Finance Working Paper

Oehler, A., \& Wendt, S. (2009). Herding behavior of mutual fund managers in Germany. Available at SSRN 1343470.

Oliver, J. D. (2005). The viable but non-culturable state in bacteria. J Microbiol,43(1), 93-100.

Ornelas, J. R. H., \& Alemanni, B. (2008). Herding behaviour by equity foreign investors on emerging markets.

Parrino, R., Poteshman, A. M., \&Weisbach, M. S. (2002). Measuring investment distortions when riskaverse managers decide whether to undertake risky projects (No. w8763). National Bureau of Economic Research.

Park, J., Konana, P., Gu, B., Kumar, A., \&Raghunathan, R. (2010). Confirmation bias, overconfidence, and investment performance: Evidence from stock message boards. McCombs Research Paper Series No. IROM-07-10.

Puckett, A., \& Yan, X. S. (2008). Short-term institutional herding and its impact on stock prices. Available at SSRN 972254.

Raddatz, C. E., \&Schmukler, S. L. (2011). Deconstructing herding: evidence from pension fund Investment behavior. World Bank Policy Research Working Paper Series, Vol. 
Redding, L. (1996). Noise traders and herding behavior.

Shaw, K. L. (1996). An empirical analysis of risk aversion and income growth.Journal of Labor Economics, 626-653.

Shiller, R. J. (2003). From efficient markets theory to behavioral finance. Journal of economic perspectives, 17(1), 83-104.

Suresh, A. (2013). Understanding Behavioral Finance Through Biases And Traits Of Trader Vis- $\mathrm{A}-\mathrm{V}$ is Investor.

Sias, R. W. (2004). Institutional herding. The Review of Financial Studies, 17(1), 165-206.

Skala, D. (2008). Overconfidence in psychology and finance-an interdisciplinary literature review. Bank iKredyt, (4), 33-50.

Venezia, I., Nashikkar, A. J., \&Shapira, Z. (2009). Herding in trading by amateur and professional investors. Available at SSRN 1358623.

Wang, D. (2008). Herd behavior towards the market index: Evidence from 21 financial markets.

Yao, S. (2010). New Sight of Herding Behavioural Through Trading Volume.

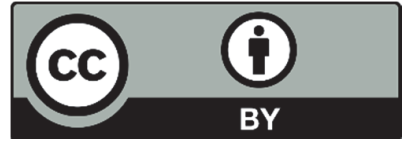

(C) 2019 by the authors; licensee Growing Science, Canada. This is an open access article distributed under the terms and conditions of the Creative Commons Attribution (CC-BY) license (http://creativecommons.org/licenses/by/4.0/). 